\title{
Localization of Glutaminase-like and Aspartate Aminotransferase- like Immunoreactivity in Neurons of Cerebral Neocortex ${ }^{1}$
}

\author{
JOHN P. DONOGHUE, ${ }^{\star, 2}$ ROBERT J. WENTHOLD,§ AND RICHARD A. ALTSCHULER‡ \\ * Laboratory of Neurophysiology, National Institute of Mental Health, and $\ddagger$ Laboratory of Neuro-otolaryngology, National Institute of \\ Neurological and Communicative Disorders and Stroke, National Institutes of Health, Bethesda, Maryland 20205; and $\$ D e p a r t m e n t ~ o f$ \\ Neurophysiology, University of Wisconsin, Madison, Wisconsin 53706
}

\begin{abstract}
The distribution of glutaminase (GLNase)- and aspartate aminotransferase (AATase)-immunoreactive cells was examined in the cerebral neocortex of rat and guinea pig and in the somatic sensorimotor and primary visual cortex of the Macaca fascicularis monkey. These enzymes are involved in the metabolism of glutamate and aspartate, two amino acids thought to be excitatory amino acid transmitters for cortical neurons.
\end{abstract}

In each of the species examined a large percentage of layer $V$ and $V I$ pyramidal neurons have pronounced glutaminase-like immunoreactivity (GLNase IR). In contrast, neurons in layers I, II, and IV show little GLNase IR. Layer III in the rat and guinea pig contains only a few, densely labeled GLNaselike-immunoreactive (GLNase-Ir) pyramidal neurons, whereas in the monkey the number of GLNase-Ir celis in layer III varies between cytoarchitectonic fields. Area $3 \mathrm{~b}$ of the primary somatic sensory cortex and area 17 (primary visual cortex) contain few GLNase-Ir cells in layer III. However, layer III contains moderate numbers of GLNase IR in cells in areas $3 a, 1,2,5$, and in the primary motor cortex. Within the motor cortex the largest pyramidal ("Betz") cells are not labeled.

In marked contrast to the results with antibody to GLNase, antibody to AATase labels cells that appear nonpyramidal in form, and these cells are in all cortical layers in each of the species examined. This distribution is roughly similar throughout all areas of rodent neocortex, but in monkey visual cortex AATase-immunoreactive neurons are more numerous in layers II-III, IVc, and VI.

When combined with the findings of other studies, our results suggest that GLNase IR marks pyramidal neurons that use an excitatory amino acid transmitter. Antibody to AATase appears to mark intrinsic cortical neurons. The AATase immunoreactivity of these cells could indicate that they use an excitatory amino acid transmitter. However, their form and distribution in cortex suggest that this antibody labels GABAergic neurons.

Received March 9, 1984; Revised March 1, 1985;

Accepted April 1, 1985

\footnotetext{
${ }^{1}$ We would like to thank Drs. Wayne Haser and Norman Curthoys for the glutaminase antisera, Marianne Parakkal and Lori Budzinski for expert technical assistance, Betty Al-Aish, Susan Wine, and Mary Lou Adams for their secretarial assistance, and Dr. E. Evarts for his comments on the manuscript.

${ }^{2}$ To whom offprint requests should be sent, at his present address: Center Neural Science, Box G, Brown University, Providence, RI 02912.
}

Neurons of the cerebral neocortex can be divided, in the most general way, into two categories: intrinsic (or local circuit) neurons and projection neurons. The intrinsic neurons, which are characterized by their multipolar, bipolar, or stellate shape, have axons that remain within a local region of cortex. It has been suggested that many of these intrinsic neurons use GABA as a transmitter (Ribak, 1978), whereas other intrinsic neurons may use peptide transmitters (see Emson and Hunt, 1981). In contrast, projection neurons have a roughly pyramidal-shaped cell body and an apical dendrite directed toward the cortical surface. Pyramidal neurons that reside in the upper cortical layers (II-III) project to other regions of cortex. Those in the deep layers may also form corticocortical connections but additionally project beyond the cortex to the striatum, thalamus, brainstem, and spinal cord (Gilbert and Kelly, 1975; Jones and Wise, 1977; Wise and Jones, 1977; Foster et al., 1981). Although corticofugal neurons are thought to have an excitatory effect on their postsynaptic targets, the synaptic transmitters of cortical pyramidal neurons have not been established. At present there is a growing body of evidence to suggest that at least some pyramidal neurons use glutamate, aspartate, or a closely related substance as their transmitter (see "Discussion"). However, it has been difficult to establish glutamate or aspartate as transmitters for these neurons and to localize such neurons histologically, since amino acids are commonly found in all cells.

We have approached the identification of excitatory amino acid neurons by attempting to develop markers that allow immunocytochemical visualization of these cells. We have suggested that routine metabolic enzymes could also serve an additional role in the synthesis, regulation, and replenishment of the neurotransmitter pools of aspartate and/or glutamate. There would then be increased levels of these synthetic enzymes in aspartergic/glutamergic neurons, and we could use increased levels of enzyme to localize these neurons immunocytochemically. Based on biochemical studies (Fonnum, 1984; Bradford and Ward, 1976; Bradford et al., 1978; Hamberger et al., 1978; Hertz, 1979; Cotman and Nadler, 1981; Wenthold, 1981; Palel et al., 1982), we have proposed two such enzymes, glutaminase (GLNase) (L-glutaminase amidohydrolase, EC 3.5.1.2) and aspartate aminotransferase (GOT, AATase) (L-aspartate: 2-oxoglutarate aminotransferase, EC 2.6.1.1) as markers for excitatory amino acid neurons. This hypothesis has been supported by studies in auditory nerve (Altschuler et al., 1981, 1984; Fex et al., 1982), relina (Altschuler et al., 1982; Lin et al., 1983), hippocampus (Altschuler et al., 1985) and other CNS areas (Wenthold and Altschuler, 1984) where glutaminase-like immunoreactivity (GLNase IR) and/or aspartate aminotransferase-like immunoreactivity (AATase IR) was observed in neurons proposed to use an excitatory amino acid transmitter. 
Accordingly, we used antiserum to GLNase and antiserum to AATase in an immunocytochemical examination of the neocortex of the rat, guinea pig, and monkey. The purpose of this study was to determine the areal and laminar distribution and the morphology of neurons in cerebral cortex that might use an excitatory amino acid transmitter.

\section{Materials and Methods}

Fifteen male Sprague-Dawley rats, 12 female $\mathrm{NIH}$ strain guinea pigs, and 1 Macaca fascicularis monkey were used in this study. All animals were perfused through the heart with $0.1 \mathrm{M}$ sodium cacodylate buffer, $\mathrm{pH} 7.4$, followed by $4 \%$ paraformaldehyde in $0.1 \mathrm{M}$ sodium cacodylate buffer. Brains were carefully removed and immersed in the same fixative for $1 \mathrm{hr}$ at $4^{\circ} \mathrm{C}$ followed by a rinse in cacodylate buffer for 16 to $20 \mathrm{hr}$ at $4^{\circ} \mathrm{C}$. Brains were dissected and 25- to 40- $\mu \mathrm{m}$ sections through different areas of the neocortex were cut with a Vibratome. In the rat and guinea pig, blocks containing frontal parietal or occipital cortex were sectioned in the frontal plane. For the monkey, blocks of tissue were removed from the somatic sensorimotor cortex and visual cortex and were sectioned in an oblique, nearly parasagittal plane. Immunoperoxidase histochemistry was then carried out using either the peroxidase-antiperoxidase (PAP) technique as described previously (Altschuler et al., 1981) or the Vectastain avidin-biotin peroxidase complex (ABC) procedure (Vector Laboratories, Inc.). The production and characterization of the antiserum to phosphate-dependent GLNase from rat kidney and antiserum to cytoplasmic AATase from swine heart have been described previously (Altschuler et al., 1981, 1984a; Curthoys et al., 1976; Wenthold and Altschuler, 1983). The antiserum to AATase has been shown to immunoreact specifically with guinea pig brain AATase in guinea pig cochlear nucleus (Altschuler et al., 1981) and with rat brain AATase in rat cerebellum (Wenthold and Altschuler, 1983) using immunoprecipitation or immunoblotting techniques with SDS gel electrophoresis. The antiserum to GLNase was similarly shown to immunoreact specifically with rat brain GLNase using whole brain homogenate (Altschuler et al., 1983). Antiserum to GLNase was used at a 1:1200 to 1:2000 dilution in phosphate-buffered saline, with $0.1 \%$ Triton X-100 for $16 \mathrm{hr}$ at $4^{\circ} \mathrm{C}$. Antiserum to AATase was applied in a similar manner at a dilution of 1:800. Adsorption controls were prepared by adding $20 \mu \mathrm{g}$ of antigen to $10 \mu \mathrm{l}$ of antiserum, bringing them to final dilution, and allowing them to preincubate for 16 to $20 \mathrm{hr}$ at $4^{\circ} \mathrm{C}$. Adsorption controls were used on nearby sections to determine nonspecific and background levels of staining. Diaminobenzidine hydrochloride was used as a chromagen to visualize reaction product. Sections were cleared, mounted, and examined with a Leitz or Zeiss photomicroscope. The distribution of densely labeled cells in selected sections was charted on line drawings of the section by using a drawing tube attached to a microscope. Sizes of labeled cells were measured in rat neocortex with a graticule in the microscope eyepiece. No correction for tissue shrinkage was made.

\section{Results}

\section{GLNase IR}

In the rat, guinea pig, and monkey, antibodies to GLNase produced granular labeling (puncta) in cell bodies and proximal portions of dendrites, whereas the nucleus was free of label. In both species of rodents and in the monkey all of the labeled cells appeared to be pyramidal neurons, based on size, shape, and dendritic labeling pattern as described below. Although nearly all cortical neurons were lightly labeled, certain neurons were much more heavily labeled both in the intensity of the label and in the number of puncta present and were, thus, qualitatively differentiable. Only these latter cells were considered positively labeled. Cell labeling was considered to be specific if no labeling was present in the same region of adsorption controls of an adjacent section. Typical GLNase-like-immunoreactive (GLNase-Ir) neurons, identified with the PAP method, are shown in Figure 1. No differences in the type or distribution of labeling were seen using either the PAP or ABC procedures. Below, we report the areal and laminar pattern of GLNase-Ir labeling in the neocortex of the rat and guinea pig and then present the pattern for the fascicularis monkey.
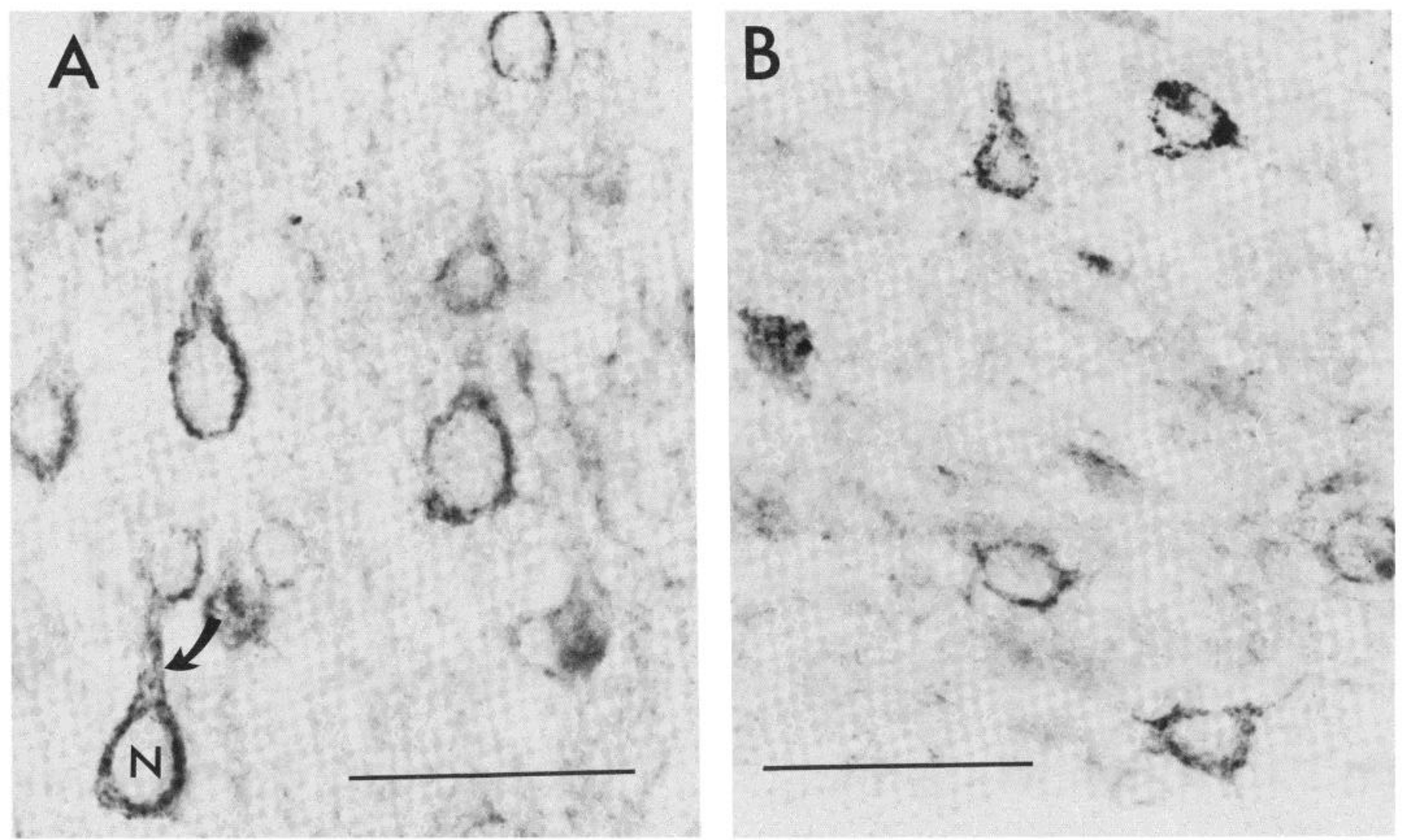

Figure 1. GLNase-Ir neurons in rat somatic sensorimotor cortex. A, labeling of pyramidal neurons in layer $\mathrm{V}$. Note granular reaction product in the perinuclear cytoplasm and in some apical dendrites (arrow) but not in the nucleus $(N)$. B, Labeling of layer VI neurons. Calibration bars $=50 \mu \mathrm{m}$. 
Rodent neocortex. In both the rat and the guinea pig, GLNase-Ir neurons were located mainly in layers $\mathrm{V}$ and VI throughout the entire cerebral neocortex. The most densely labeled cells were found in the deep part of layer VI and within the white matter itself. These GLNase-IR cells had triangular or ovoid somata measuring 13 to 20 $\mu \mathrm{m} \times 8$ to $20 \mu \mathrm{m}$. For these cells the mean diameter across the base was $15.97 \pm 1.92 \mu \mathrm{m}(\mathrm{SD}, N=25)$. Some GLNase-Ir neurons contained label that extended for a short distance (up to $100 \mu \mathrm{m}$ ) into a process directed toward the pial surface (Fig. 1B). These features are typical of pyramidal cells found in layer $\mathrm{VI}$, although some nonpyramidal cells may have a similar appearance. In addition to perisomatic labeling, a diffuse background labeling was also present throughout layer VI. This label did not appear to be contained within fibers nor could it be associated with any other cellular structures.

GLNase-Ir cells in layer $V$ included small, medium, and large pyramidal neurons (Figs. $1 A$ and $2 A$ ), ranging from 10 to $22 \mu \mathrm{m}$ across the base. Although this range was slightly greater than for layer $\mathrm{VI}$ cells, the mean size was nearly the same $(15.59 \pm 2.67$, SD). The superficial one-half of layer $V$ contained the majority of
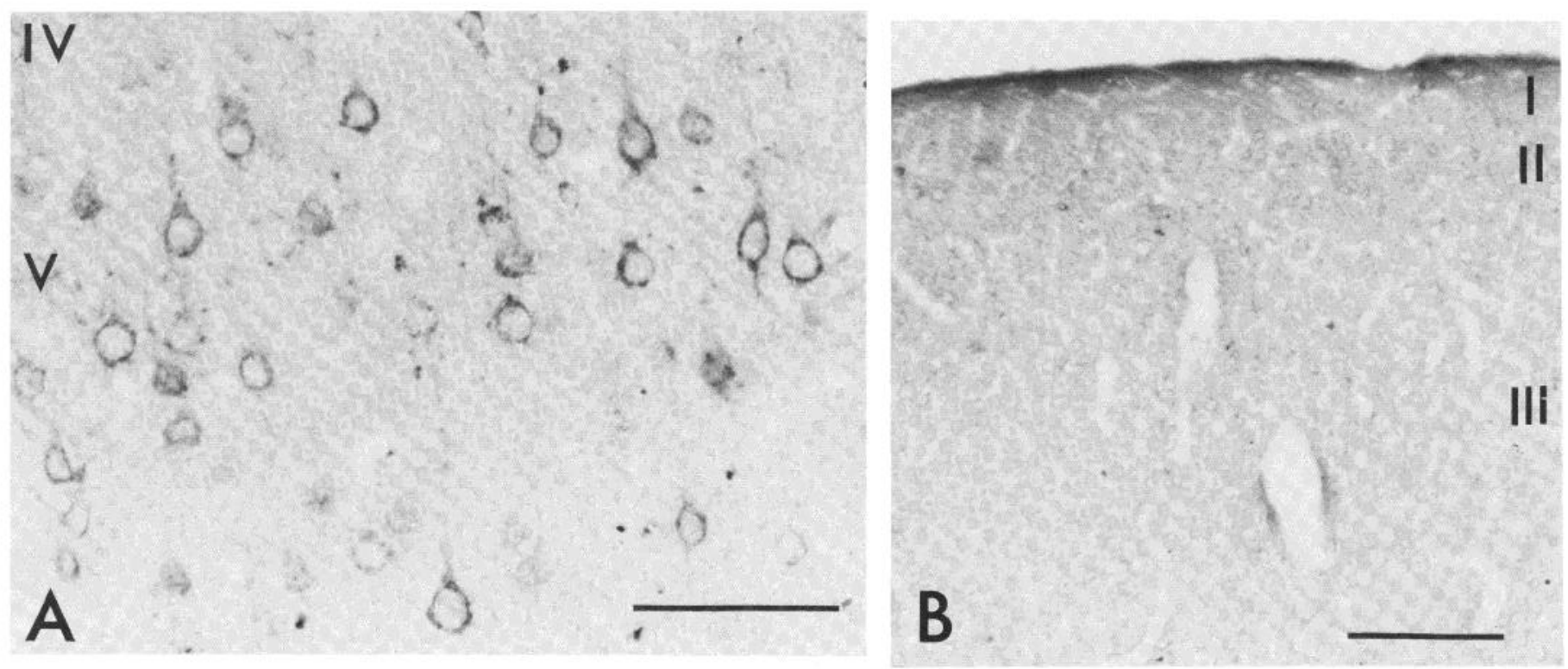

Figure 2. GLNase $\mathbb{R}$ in rat somatic sensorimotor cortex. A, Labeled pyramidal cells in the superficial part of layer V. Note the lack of labeling in the adjacent part of layer IV. B, Lack of GLNase IR in layers I to III. Calibration bars: $A=100 \mu \mathrm{m} ; B=200 \mu \mathrm{m}$.

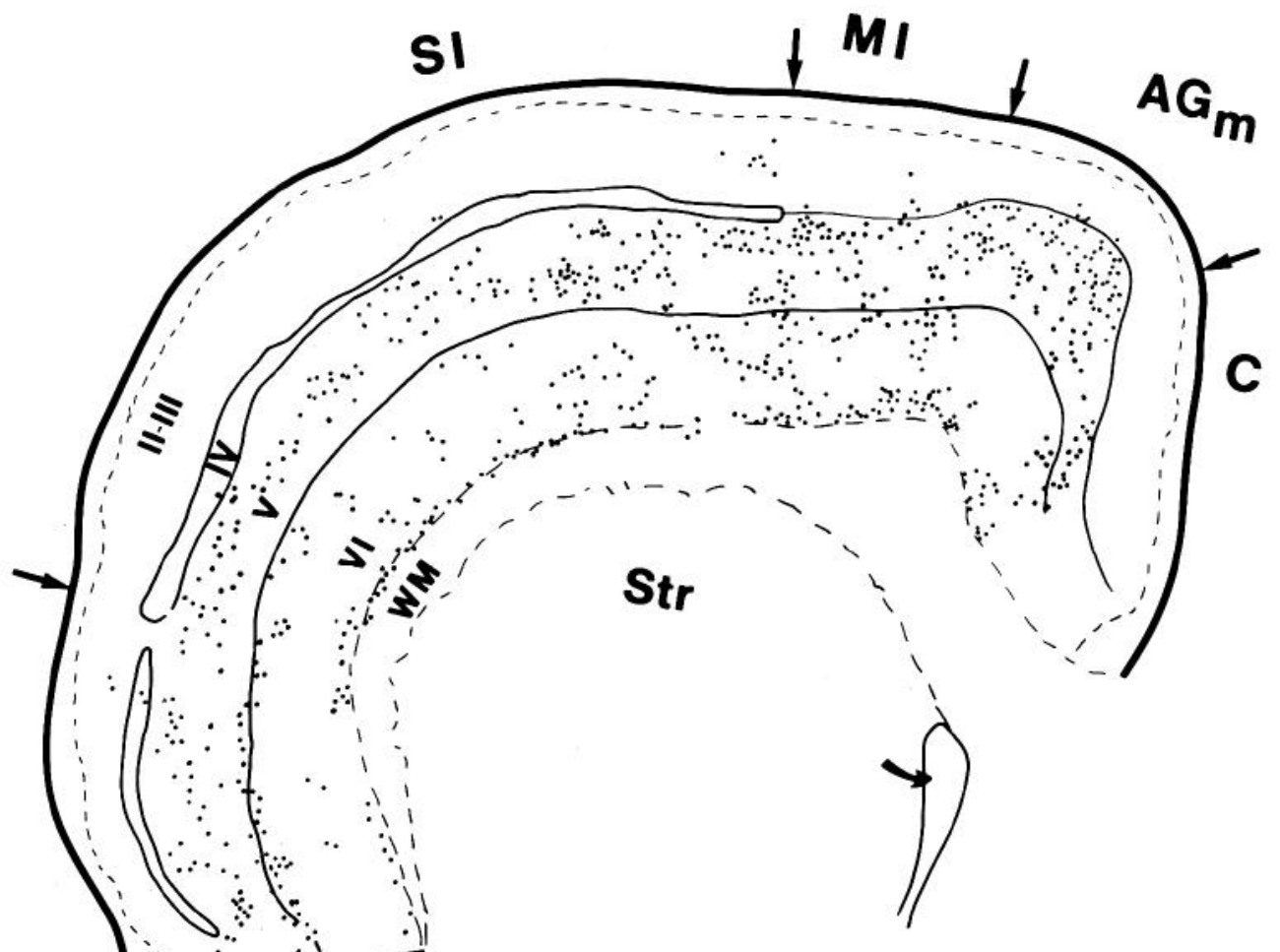

Figure 3. Distribution of neurons showing GLNase IR charted on a transverse section through the rat parietal cortex. Each dot represents a single GLNase-Ir cell. Cytoarchitectonic boundaries are indicated by arrows and the location of granule cells in layer IV is outlined. $A G_{m}$, medial part of frontal agranular cortex: $C$, cingulate cortex; Str, neostriatum; WM, subcortical white matter. 
labeled cells, but GLNase-Ir neurons were also present in the deeper part of this layer as well. Some pyramidal cells in the deep. part of layer $\mathrm{V}$ had an intermediate level of labeling that was greater than the general level of background cellular labeling, but was still considerably less dense than that in the darkly labeled layer $\mathrm{V}$ and $\mathrm{VI}$ neurons. In all chartings (Figs. 3, 6, 10, and 11) cells with moderate GLNase IR have not been included as "labeled" neurons.

GLNase-Ir neurons were present in the laminae superficial to layer $V$, but densely labeled cells were infrequent and were largely restricted to layer III. Pyramidal neurons with intermediate levels of labeling as described above were also commonly observed in layer III. In contrast, neurons in layers I, II, and IV showed little or no GLNase IR (Fig. 2B).

Sections taken from frontal, parietal, temporal, and occipital cortex were examined in both rat and guinea pig. The predominantly infragranular distribution of GLNase IR was essentially the same in all cortical areas in these rodents. Figure 3 shows the distribution of all densely labeled neurons found in a single coronal section at a level taken approximately through the middle of the rat somatic sensorimotor cortex. This section was chosen because it contains a number of cortical fields that can be identified by their cytoarchi- tecture, including the primary somatic sensory cortex (SI; Welker, 1976), primary motor cortex (Ml; Donoghue and Wise, 1982), and cingulate cortex, as well as cortical areas near the rhinal sulcus. The location of cytoarchitectonic areas was determined by counterstaining sections with thionin after charting the location of labeled cells. The charting illustrates that GLNase-Ir neurons are numerous in layers $\mathrm{V}$ and VI, whereas few GLNase-Ir neurons are present in layer III throughout the cortex. This predominantly infragranular labeling pattern was consistently seen in every rat and guinea pig examined.

Monkey neocortex. Sections through the somatic sensorimotor and visual cortex were examined for GLNase IR in one monkey. Several series of separately reacted sections were examined because tissue was available only from this single animal and the same labeling pattern was observed in each series. Neurons contained granular puncta of GLNase IR that were identical to that observed in the rat and guinea pig (Figs. 4 and 5). As in the rodents, GLNaseIr neurons were common in layers $\mathrm{V}$ and $\mathrm{VI}$ throughout the neocortical areas examined. However, in contrast to the pattern seen in rodents, the superficial layers of certain cortical fields also contained many GLNase-Ir neurons.

The distribution of GLNase-Ir neurons in the somatic sensorimotor
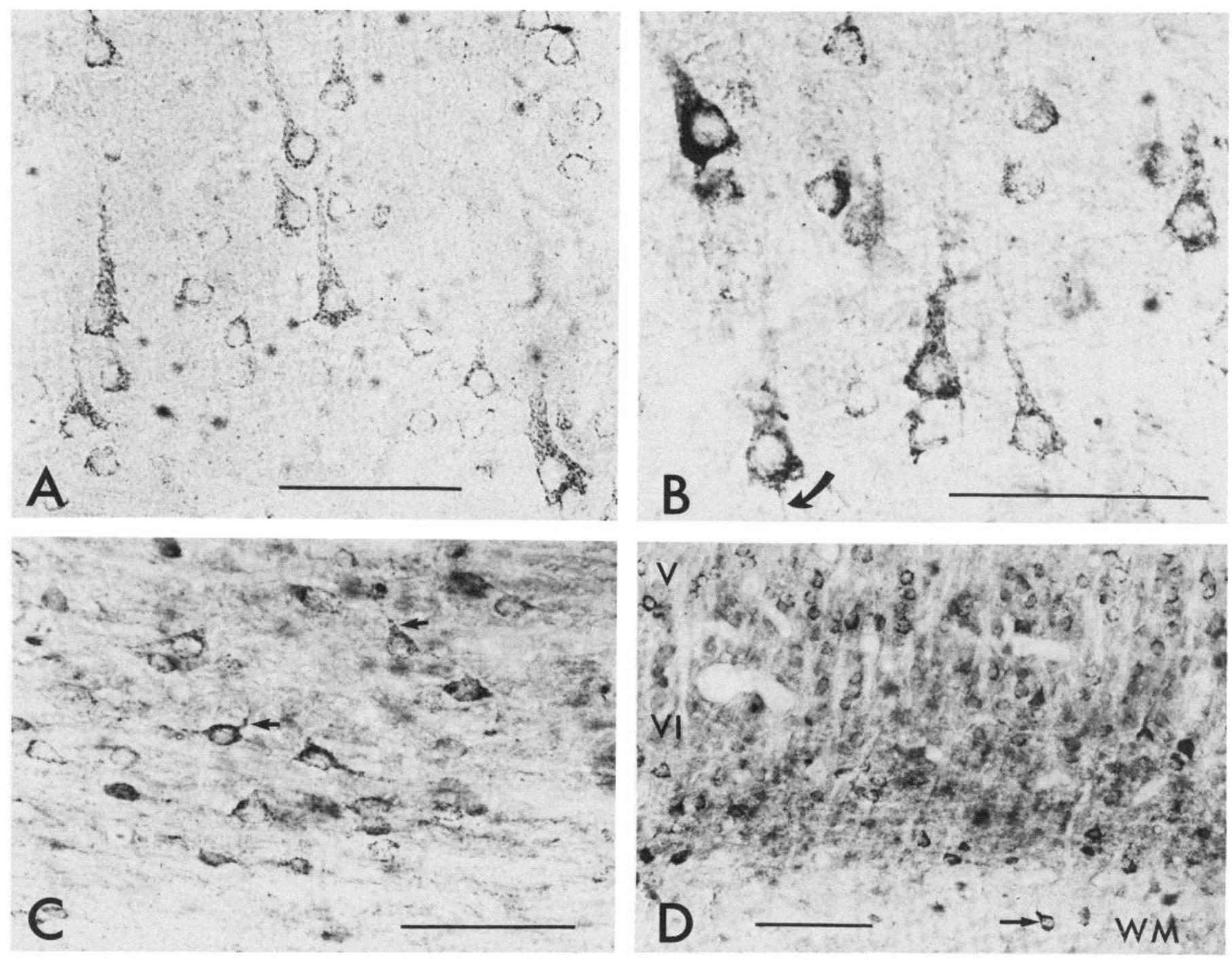

Figure 4. GLNase-Ir neurons in monkey somatic sensorimotor and visual cortex. $A$ and $B$, Examples of large, densely labeled layer III neurons in area 5. The curved arrow in $B$ marks the labeling of what appears to be the initial component of an axon. $C$, GLNase-Ir neurons in layer VI of area $3 b$ (SI cortex). $D$, Labeled cells in layers $\mathrm{V}$ and $\mathrm{VI}$ in area 17. The arrow marks a labeled neuron in the subcortical white matter (WM). Calibration bars: $A$ to $C=100 \mu \mathrm{m} ; D=$ $200 \mu \mathrm{m}$. 

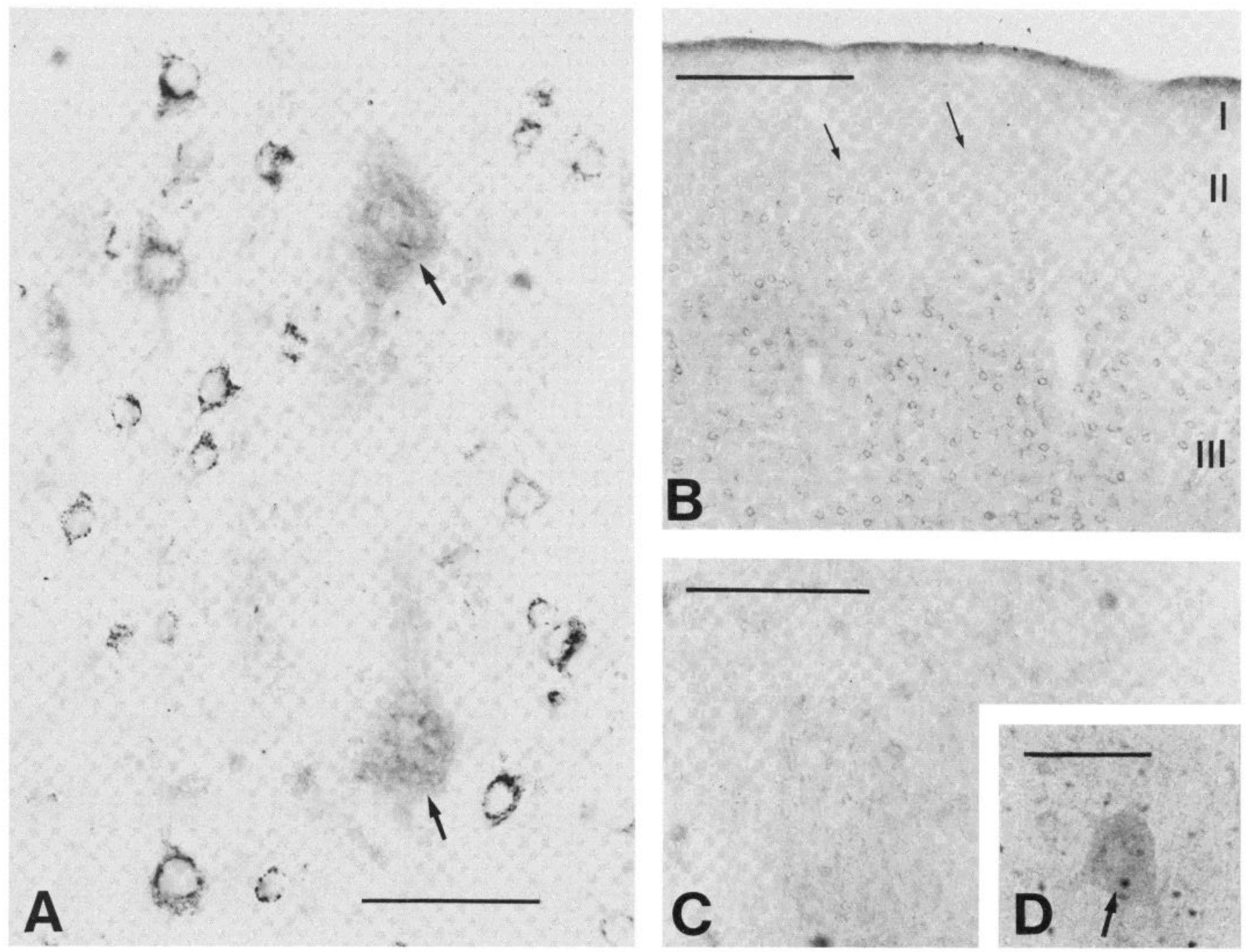

Figure 5. GLNase IR in monkey Ml cortex (area 4). A, Labeling of small and medium-sized pyramids in layer V. Giant "Betz" cells (arrows) are not considered to be labeled since they are also labeled in adsorption controls (see $D$ ). $B$, labeling of numerous cells in layer III and in all but the most superficial part of layer II (arrows). $C$ and $D$, Absorption controls. Calibration bars: $A, C$, and $D=50 \mu \mathrm{m} ; B=500 \mu \mathrm{m}$.

region is shown in Figure 6 . Within $\mathrm{SI}$, which in macaques includes four cytoarchitectonic areas $(3 \mathrm{a}, 3 \mathrm{~b}, 1$, and 2 ; identified by features described in Jones et al, 1978), GLNase-Ir cells were numerous in layers V and Vl. Pyramidal cells of all sizes were densely labeled in each of these cortical fields (Fig. 4), and, as in rodent neocortex, GLNase-Ir cells tended to be more numerous and more densely labeled in the upper part of layer $V$ and in the deepest part of layer VI. In addition to this infragranular group of labeled cells, the number of labeled layer III neurons successively increased in cytoarchitectonic fields caudal to area $3 \mathrm{~b}$. This trend continued beyond $\mathrm{SI}$ into the posterior parietal area 5 (Fig. 6). Thus, the pattern in area $3 b$ most resembled the labeling in rodent neocortex, because there were relatively few GLNase-Ir neurons in layer III. Areas 2 and 5 were most unlike the rodent pattern because layer III contained many labeled neurons. Within these two areas the largest layer III pyramidal cells were among the most densely labeled neurons observed (Fig. $4, A$ and $B$ ). Layers I, II, and IV rarely had GLNase-Ir neurons and the extent of layer IV was made evident by its paleness, compared to the neighboring layers. In this entire postcentral region layer III often contained moderately labeled pyramidal cells that closely resembled neurons with intermediate levels of labeling in the rat and guinea pig.
Area 4, the primary motor cortex (MI), was markedly different in its appearance from the other cortical areas examined (Figs. 5 and 6). Beginning near the MI-SI boundary in the central sulcus, there was an abrupt increase in the number of GLNase-Ir neurons in layers II and III that extended throughout MI (Figs. 5 and 6). Neurons in the upper part of layer II in MI, as in all cortical areas, were at background level of labeling. Thus, GLNase-Ir neurons in MI formed a continuous zone of labeled cells that extended from the lower part of layer II to the subcortical white matter. Most of the labeled cells appeared to be small to medium-sized pyramidal neurons. However, not all pyramidal cells were labeled. It is particularly noteworthy that the largest pyramidal cells, the "Betz" cells, which are known to project to the spinal cord (Murray and Coulter, 1981), did not contain granular reaction product. However, these neurons did have a pale, homogeneous labeling of the soma that was considered to be nonspecific because these neurons were also labeled in adsorption controls (Fig. 5).

In area 17, GLNase-Ir neurons were mainly found in layers $V$ and VI (Fig. 7). As in the other areas examined, darkly labeled cells were also present in the subcortical white matter. A few GLNase-Ir neurons were present superficial to layer $\mathrm{V}$, including the large pyramidal cells of layer IV. Small layer IV cells were not GLNase-Ir. 


\section{AATase IR}

Antibody to AATase produced a pattern of labeling that was entirely different from the GLNase-Ir pattern. Rather than the granular GLNase reaclion product, AATase antibody produced homogeneous labeling in somata and occasionally in proximal parts of cell processes (Figs. 8 and 9). Nuclei were unlabeled. AATase-likeimmunoreactive (AATase-Ir) cells were evident in all of the cortical areas we examined in rat, guinea pig, and monkey, but AATase-ir fibers or terminals were not apparent. Antibody to AATase did not appear to label glial cells.

Rodent neocortex. In the rat and guinea pig, labeled cells were present in all layers and were widely spaced, in contrast to the dense, banded pattern of GLNase-Ir neurons. Chartings of the labeling in the rat somatic sensory and visual cortex (Fig. 10) exemplify the pattern found in all cortical fields of both rat and guinea pig. AATase-Ir neurons of varied size and shape were present in all layers, and no striking laminar segregation was evident. Labeled cells had rounded cell bodies from about 10 to $20 \mu \mathrm{m}$ in diameter or were spindle shaped with cell bodies as large as $14 \times 28 \mu \mathrm{m}$, with the long axis of the cell oriented perpendicular to the pial surface. The mean size of labeled cells was $14.1( \pm 2.7 \mu \mathrm{m}, \mathrm{SD}) \times$ $17.8 \mu \mathrm{m}( \pm 4.2, \mathrm{SD})$. Many labeled cells had radially oriented dendritic processes (Fig. $8 A$ ) but a few appeared to have only thin apical and basal processes and a spindle-shaped cell body (Fig. 8C), characteristic of bipolar or bitufted neurons (Peters et al., 1983). These features indicate that AATase-Ir cells correspond mainly to nonpyramidal, local circuit neurons. It was difficult to classify AATase-Ir neurons with limited labeling as pyramidal or nonpyramidal; therefore, some pyramidal neurons may have also been labeled. However, the vast majority appeared to be nonpyramidal neurons, based on the morphological features revealed by the reaction product.

Monkey visual cortex. The pattern of labeling in the monkey from the AATase antibody was examined only in the primary visual cortex. The distribution of AATase-Ir neurons in area 17 is illustrated in Figure 11. The AATase-Ir neurons appeared to be nonpyramidal cells, similar in size and shape to those present in rat and guinea pig. The small neurons that are abundant in layer IVC of monkey visual cortex were not labeled. Within the visual cortex, AATase-Ir neurons occurred in all layers. AATase-Ir neurons were largely localized to three tiers: one in layers II-III, one in layer IVC, and one in layer VI. By contrast, layers I, IVAB, and $V$ contained relatively few AATase-Ir neurons.

\section{Discussion}

The present study has shown that selective sets of cortical neurons label with antibodies to GLNase or to AATase. GLNase IR appears to be present mainly in pyramidal cells of layers $V$ and $V I$ except in the monkey, where GLNase-Ir neurons are also present in layer III of certain cortical fields. In contrast, AATase IR is present mainly in cells with features of nonpyramidal neurons, and these cells are widely distributed in all cortical layers and areas. A primary question raised by these findings is whether an enrichment of enzyme related to glutamate or aspartate synthesis marks neurons that use these amino acids in neurotransmission. For the cortex, a strong case can be made for GLNase as a marker for neurons that

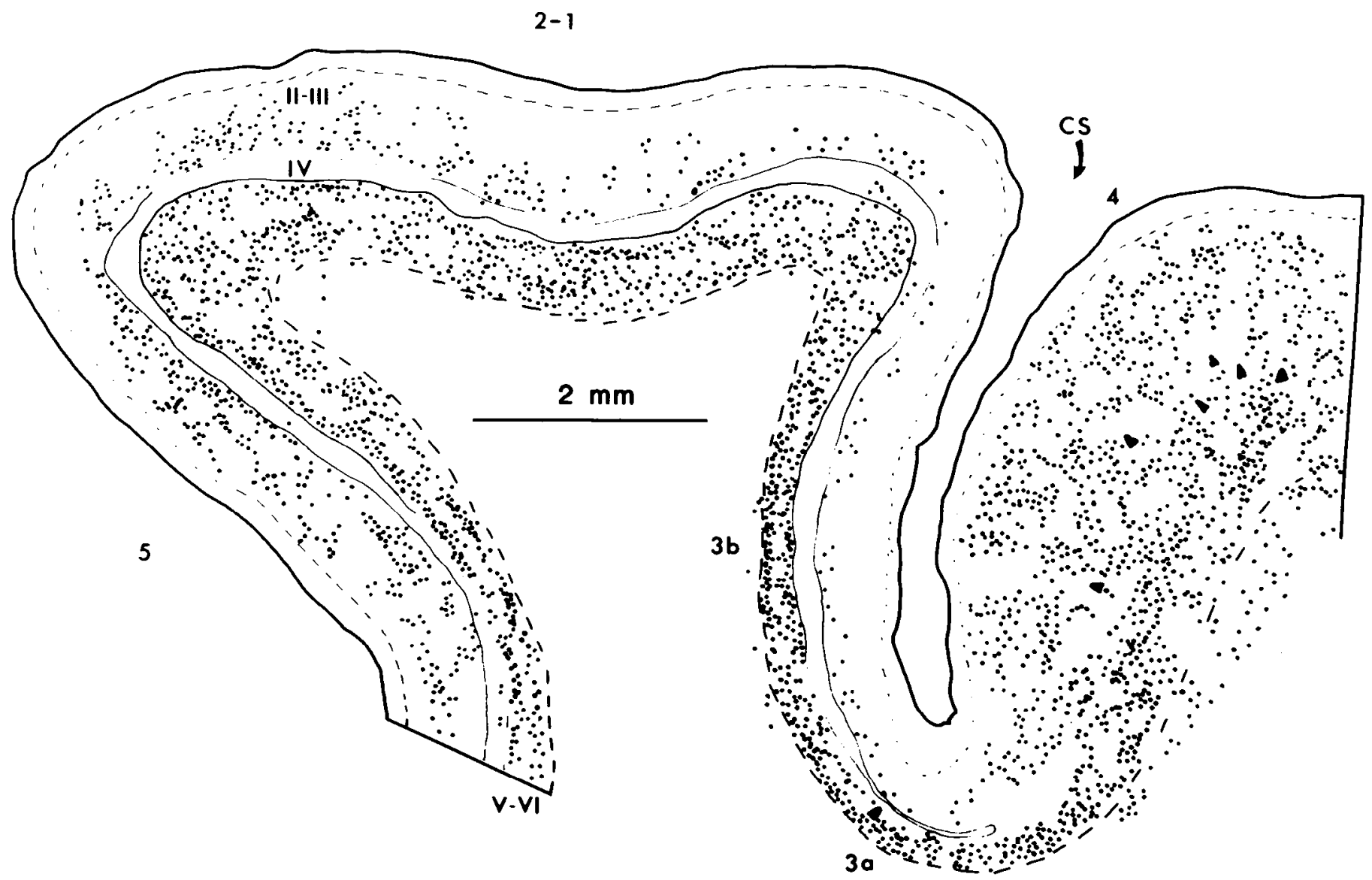

\section{MONKEY SOMATIC SENSORIMOTOR CORTEX GLUTAMINASE}

Figure 6. Distribution of GLNase-Ir neurons in monkey somatic sensorimotor cortex, parasagittal section near the area of the hand representation in SI and Ml. Rostral is to the right. Each dot represents one labeled cell. Triangles in area 4 mark the position of "Betz" cells, which are not GLNase-Ir. Note that there are relatively few labeled cells in the superficial layers in area $3 \mathrm{~b}$, compared to area $4(\mathrm{Ml})$ or areas 1,2, or 5 . CS, central sulcus. 


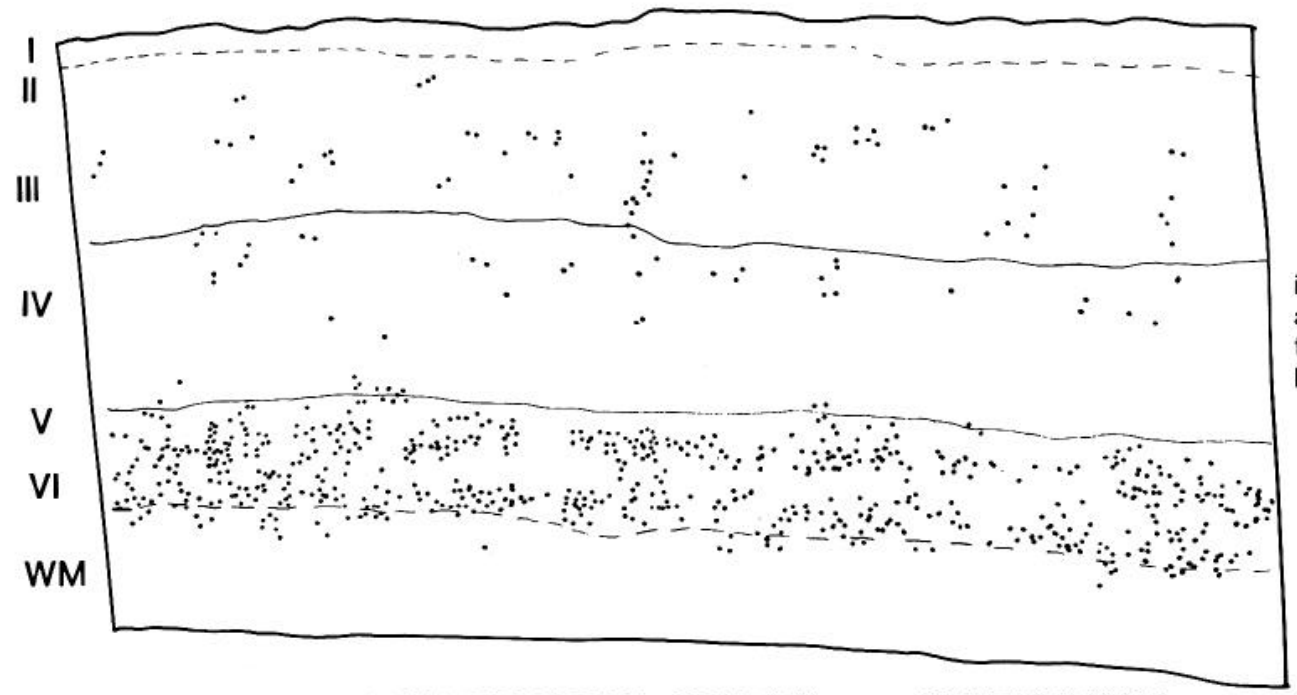

Figure 7. Distribution of GLNase-Ir neurons in monkey visual cortex (area 17). Most cells are present in layers $\mathrm{V}$ and $\mathrm{Vl}$, but a few are found in layers III and IV. Labeled cells in layer IV appeared to be pyramidal neurons.

\section{MONKEY VISUAL CORTEX GLUTAMINASE}
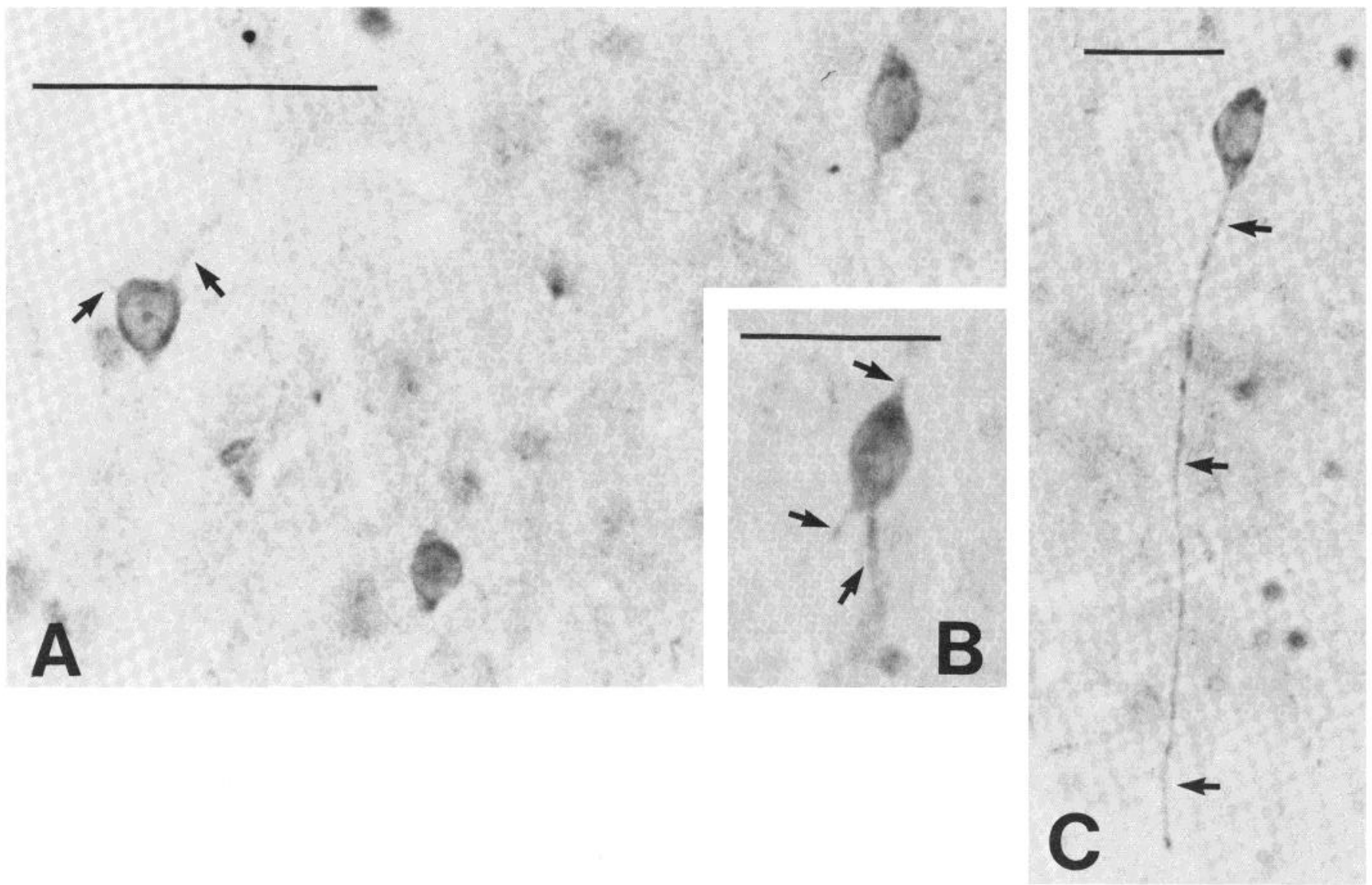

Figure 8. AATase-Ir neurons in rat cortex. $A$ and $B$, Labeled cells in somatic sensorimotor cortex. Cells have a relatively homogeneous labeling of their cytoplasm and proximal parts of dendrites (arrows). C, Labeled layer III neuron in visual cortex. Note labeling of basilar process (arrows). Calibration: $A$ and $C, 100 \mu \mathrm{m} ; B, 50 \mu \mathrm{m}$.

use an excitatory amino acid transmitter, whereas the results for AATase are less clear.

GLNase IR as a marker for glutamergic neurons. Antibody to GLNase labeled numerous cells with similar morphology and distinct laminar distribution. Two observations indicate that dense GLNase IR is largely found in pyramidal cells. First, the somatic and limited dendritic labeling of GLNase-Ir neurons revealed morphological features of cells that strongly resemble pyramidal neurons. Second, 


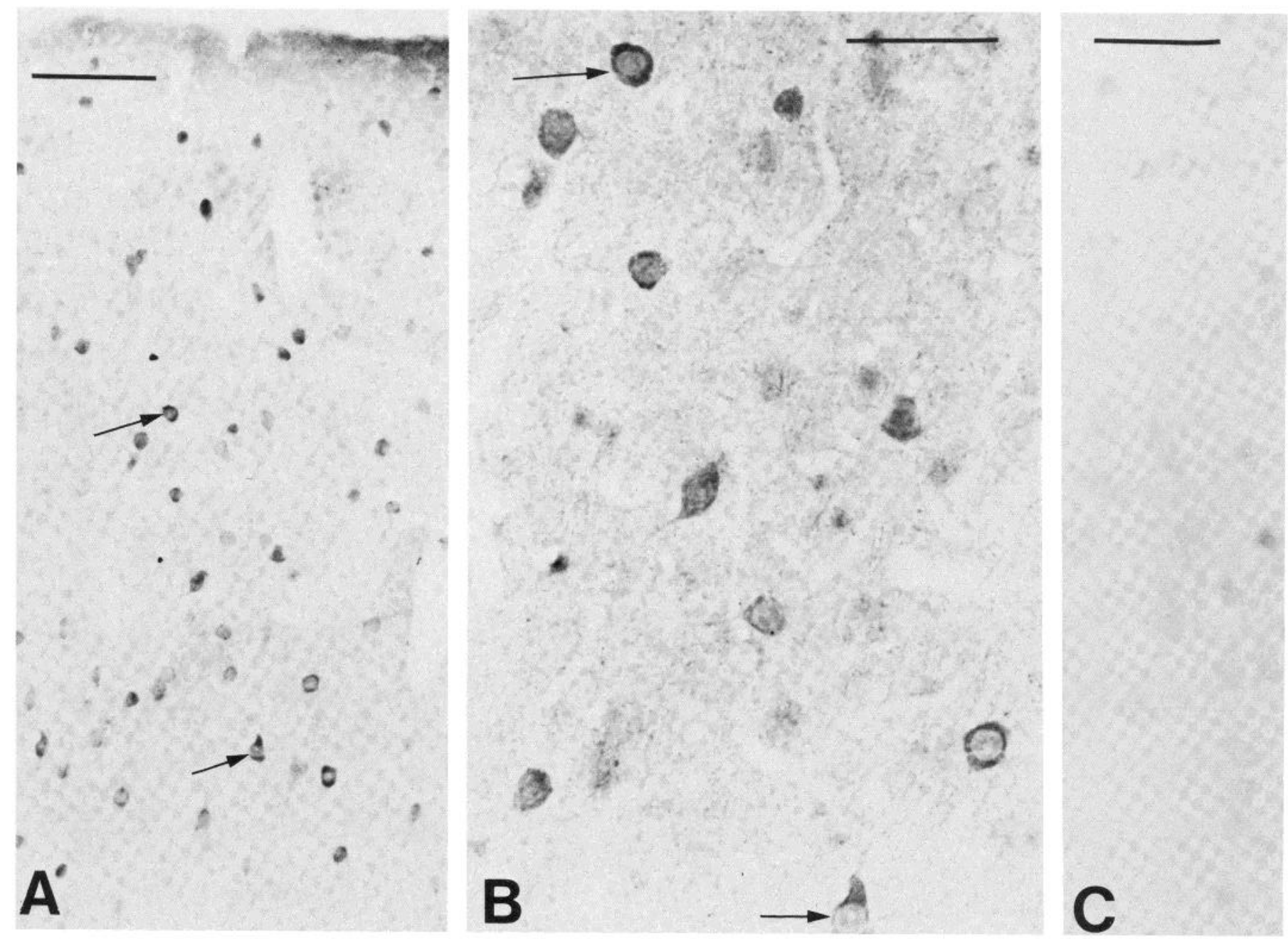

Figure 9. AATase IR in rat visual cortex at low $(A)$ and higher $(B)$ magnification. Arrows denote the same neurons in each panel. $C$, AATase adsorption control. Calibration: $A, 100 \mu \mathrm{m} ; B$ and $C, 50 \mu \mathrm{m}$.

GLNase-Ir neurons are found in great numbers in layers $\mathrm{V}$ and $\mathrm{VI}$, which are both largely composed of pyramidal neurons. However, we cannot rule out the possibility that, using only the morphological features revealed by immunocytochemical staining, some GLNaseIr neurons are in fact nonpyramidal.

The enrichment of GLNase in cortical neurons, as revealed by dense GLNase IR, indicates that these neurons may be producing large quantities of an excitatory amino acid for use as a neurotransmitter. There is now abundant evidence that glutamate, aspartate, or a closely related substance is a cortical transmitter. Glutamate is present in high concentration in cerebral cortex (Berl and Waelsch, 1958) and appears to be released from cortical neurons (Reubi and Cuenod, 1979; Baughman and Gilbert, 1981) following cortical stimulation. Glutamate and aspartate excite cortical target neurons (Krnjevic and Phillis, 1963; Curtis and Johnston, 1974), and cortical targets possess specific receptors for glutamate (Henke and Cuenod, 1980). Moreover, the postsynaptic effect of these amino acids can be blocked by receptor antagonists (Stone, 1973, 1976; Spencer, 1976; Hicks and Guedes, 1983). Furthermore, high affinity uptake sites for glutamate and aspartate (Logan and Snyder, 1971; Divac et al, 1977; Soreide and Fonnum, 1980) are decreased in number by cortical ablations (McGeer et al., 1977; Bromberg et al., 1981; Young et al., 1981; Nieoullon and Dusticier, 1983).

Throughout the cortex a large percentage of layer $\mathrm{V}$ and $\mathrm{VI}$ neurons were GLNase-Ir. Based on the knowledge that corticofugal neurons reside chiefly, if not entirely, within layers $\mathrm{V}$ and $\mathrm{Vl}$, it is likely that many corticofugal neurons are GLNase-Ir. Moreover, considerable evidence suggests that most layer $\mathrm{V}$ and $\mathrm{VI}$ corticofugal neurons use an excitatory amino acid transmitter. Cortical projections from layer $\mathrm{V}$ neurons to the neostriatum (Spencer, 1976; Divac et al., 1977; Kim et al., 1977; McGeer et al., 1977; Reubi et al., 1978; Emson and Lindvall, 1979; Stone, 1979; Streit, 1980; Fonnum et al., 1981; Hassler et al., 1982), red nucleus (Bromberg et al., 1981), pons (Thangnipon et al., 1980), and dorsal column nuclei (Stone, 1973, 1976; Rustioni and Cuenod, 1982) have each been suggested to use an excitatory amino acid transmitter. Although corticospinal and corticotectal projections have also been reported to use an excitatory amino acid transmitter (Lund-Karlsen and Fonnum, 1978; Young et al., 1981), these findings have been disputed (Baughman and Gilbert, 1981; Singer et al., 1981). There is some evidence that corticothalamic projections, which arise largely from layer $\mathrm{VI}$ pyramidal neurons, also use an excitatory amino acid transmitter (Young et al., 1978; Baughman and Gilbert, 1981; Kerkerian et al., 1983; Fonnum, 1984). Thus, these findings, coupled with the presence of GLNase IR in a large number of layer $V$ and $V I$ pyramidal cells, are consistent with the conclusion that GLNase IR marks the somata of excitatory amino acid neurons that give rise to these subcortical projections, but the demonstration of GLNase labeling of specific projections will require labeling with both GLNase antibody and an anatomical tracer. The uniform GLNase-Ir labeling pattern of infragranular pyramidal neurons may suggest that the transmitter for layer V and VI neurons is similar across areas and across species. 


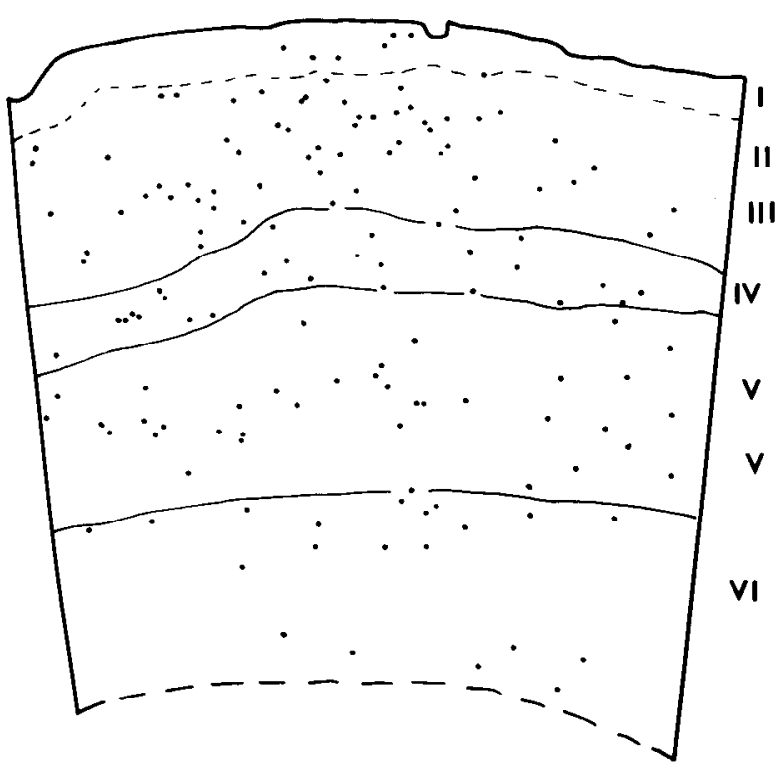

SOMATIC SENSORY CORTEX

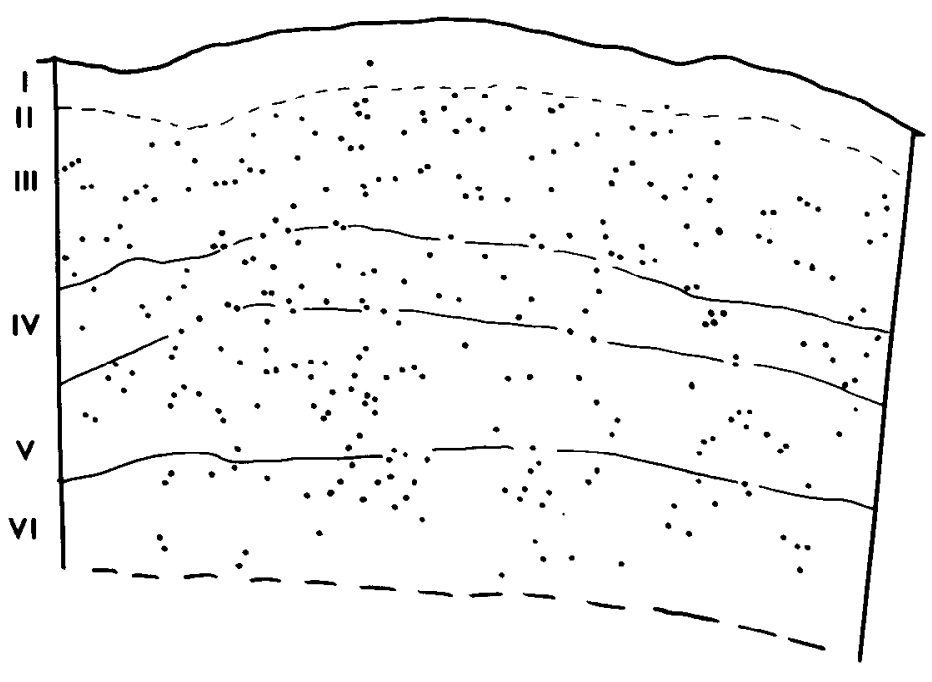

VISUAL CORTEX

\section{RAT AAT}

Figure 10. Distribution of AATase-Ir neurons in rat somatic sensory cortex (left) and visual cortex (right). Each dot represents one cell.

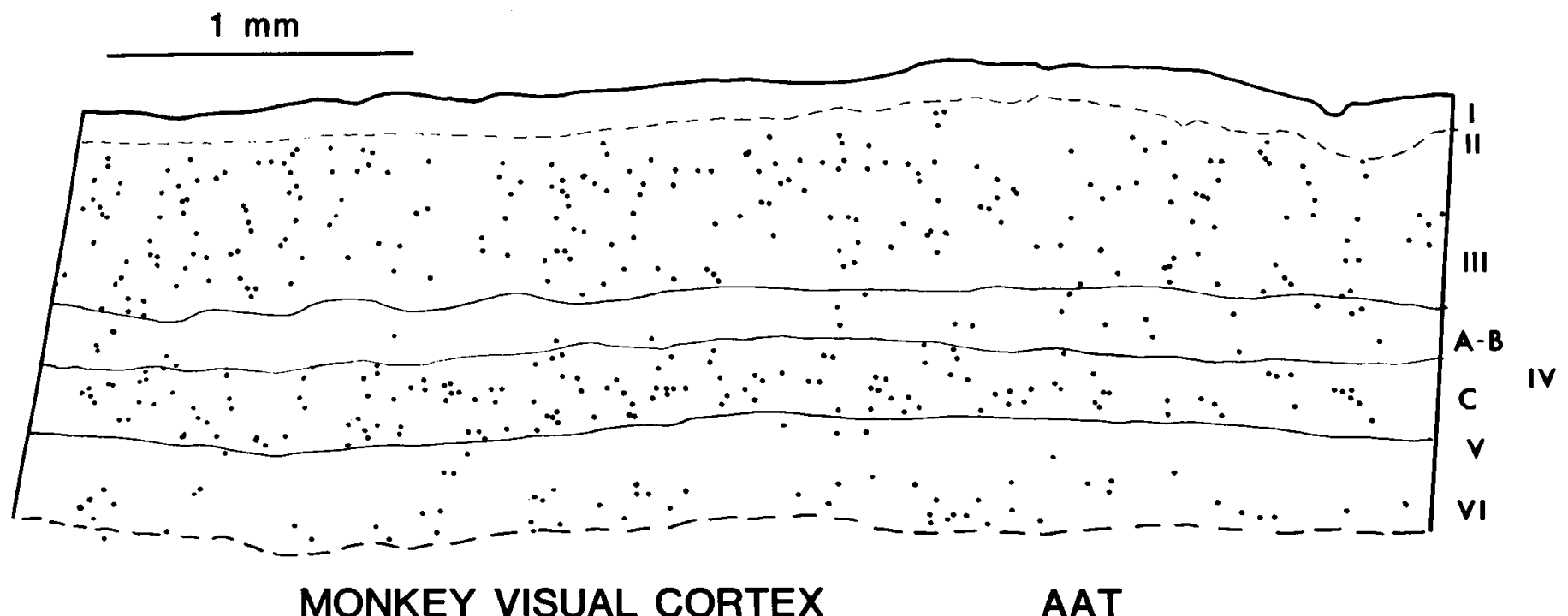

Figure 11. Charting of AATase-Ir neurons in monkey visual cortex. Note that, although labeled cells are found in layers II to $\mathrm{VI}$, relatively few are presen. in layers IVA-B, and V.

However, it remains quite possible that there are other transmitters of corticofugal neurons. For example, at least one set of corticofugal neurons, the "Betz" cells, which are known to project to the spinal cord, are not GLNase-lr.

In both of the rodent species examined, antibody to GLNase did not label large numbers of pyramidal neurons in the supragranular layers. Similarly, in the monkey, GLNase-Ir cells were infrequent in layers I, II, and III of somatic sensory area $3 \mathrm{~b}$ and in primary visual cortex, but GLNase-Ir neurons were present in layer III of motor cortex, areas 1 and 2 of SI cortex, and in area 5. The occurrence of labeled cells in supragranular layers of specific architectonic fields indicates that there are areal and species differences in GLNase IR, but this finding requires confirmation in additional monkeys.

In accord with the presence of GLNase-Ir layer III cells, the results of two studies indicate that some supragranular pyramidal neurons use glutamate or aspartate as a transmitter and that these cells form corticocortical connections. First, injections of $\left[{ }^{3} \mathrm{H}\right]$-D-aspartate into area 19 of cat visual cortex label layer III corticocortical neurons in area 17. This finding suggests that these cells use an excitatory transmitter if it is assumcd that glutamergic or aspartergic neurons selectively take up and transport D-aspartate. Second, the excitatory effect of both ipsilateral and contralateral corticocortical inputs is blocked by specific amino acid antagonists (Hicks and Guedes, 1983). Fonnum et al. (1981) also concluded that some commissural neurons may use an excitatory amino acid in rats becausc there is a small but significant decrease in high affinity uptake of glutamate in cingulate cortex following ablation of the contralateral cortex. However, this finding does not require the presence of layer III 
commissural neurons because cells in the deeper layers contribute to this projection in the rat (Vogt et al., 1981). Thus, these layer $V$ and $\mathrm{VI}$ commissural cells could account for small changes in high affinity uptake.

The small percentage of densely GLNase-Ir neurons in the supragranular layers indicates that there are additional transmitters for layer II-II corticocortical neurons. In support of this idea, Morrison et al. (1983) have presented immunocytochemical evidence that somatostatin (SST) may be a transmitter for some corticocortical neurons. Alternatively, some cortical pyramidal neurons may use an excitatory amino acid transmitter that is synthesized through a different metabolic pathway and are, therefore, not GLNase-Ir. A number of pyramidal cells in layers $I I$ and $V$ showed intermediate levels of GLNase IR. The comparatively weak labeling of these cells indicates that they contain low levels of glutaminase, but this labeling, too, could mark neurons that use an excitatory amino acid transmitter. It would be useful to develop other markers of glutamergic neurons to clarify this issue.

In summary, the studies cited above suggest that glutamate or a related amino acid is a transmitter for many corticofugal pathways and for some intracortical projections. These data closely correspond to our findings that many layer $V$ and $V I$ neurons and a few layer III neurons are GLNase-Ir. This close correspondence suggests that GLNase IR marks specific classes of cortical projection neurons that use an excitatory amino acid transmitter.

AATase as a transmitter-specific marker in cortex. The form and distribution of AATase-Ir cells were markedly different from those observed with GLNase antibody. Most AATase-Ir cells appeared to be nonpyramidal neurons based on the bipolar or multipolar configuration revealed by somatic and proximal dendritic labeling. However, the restricted nature of the dendritic labeling in our material does not exclude the possibility that some pyramidal cells are labeled by this antibody. Compared to GLNase IR, relatively few neurons were AATase-lr and these cells were found in all layers, without marked laminar segregation. This combination of morphological features, limited numbers, and laminar distribution indicates that AATase labels a different population of neurons than GLNase antibody and that the majority of these cells are intrinsic, nonpyramidal neurons.

Recent studies have shown that cortical nonpyramidal neurons may use any of a number of putative transmitters including cholecystokinin (CCK) (Innis et al., 1979; Emson and Hunt, 1981; Peters et al., 1983), vasoactive intestinal polypeptide (VIP) (McDonald et al., 1982; Morrison et al., 1983), enkephalin (ENK) (McGinty et al., 1984), and GABA (Ribak, 1978). Thus, on the basis of their nonpyramidal form alone, it is possible that AATase antibody marks neurons that also contain these other transmitter candidates. However, there are features of the laminar distribution of certain of these groups of peptidergic neurons that make co-localization with AATase IR more or less likely. For example, SST, like AATase antibody, marks neurons having a variety of shapes and sizes, but SST-Ir neurons are primarily found in layers II, III, and VI (Bennet-Clarke et al., 1980; McDonald et al., 1982; Morrison et al., 1983), whereas AATase-ir neurons are present in all cortical layers. Similarly, VIP (McDonald et al., 1982; Morrison et al., 1983), CCK (Peters et al., 1983), and ENK (McGinty et al., 1984) neurons show laminar distributions that are more specific than that of AATase-Ir neurons. Thus, it seems unlikely that antibody to AATase only marks neurons containing these peptides, although certain classes of peptide-containing cells may be included in this population.

By contrast, both GABA-containing and AATase-Ir neurons in rat and monkey are present in all layers, both have similar nonpyramidal forms, and both occur in a wide range of diameters (Ribak, 1978; Hendrickson et al., 1981; Hendry and Jones, 1981). Furthermore, both lypes of neurons show similar species-specific variations. In rat visual cortex AATase-Ir and GABA neurons are distributed rather homogeneously throughout the depth of cortex and the frequency of both is remarkably similar (Ribak, 1978; Chronwall and Wolf,
1980). In the monkey, AATase-Ir neurons and GABAergic neurons have a similar frequency and both are found in greater numbers in layers II, III, IVC, and VI, whereas relatively fewer of both are found in layers I, IVAB, and V (Hendrikson et al., 1981). Double labeling with both markers would, of course, present conclusive evidence that AATase IR marks GABA-containing neurons in cortex. Nevertheless, the coincidences presented above could suggest that AATase levels are elevated in some GABA neurons. However, it remains possible that AATase-Ir neurons are a separate class of intrinsic neurons that use an excitatory amino acid or some other unidentified transmitter. There have been no previous suggestions for aspartate or glutamate as a transmitter of local circuit neurons.

Transmitters of unlabeled cells. Although antibodies to AATase and GLNase marked a large number of cells in cortex, the vast majority of neurons in layers $\|$ and IV, and a varying number of cells in other layers, were not labeled with these antisera. If these cells produce an excitatory amino acid transrnitter by a syrithetic route that does not employ GLNase or AATase, they could contain relatively low levels of these enzymes and would not be labeled by our antibodies. Furthermore, as discussed above, there are a number of other transmitter candidates for cortical neurons and these could account for a portion of unlabeled cells. However, it is noteworthy that, even after considering all of these candidates, the transmitter is unknown for a large percentage of pyramidal cells in the superficial cortical layers and for the "spiny stellate" cells that are abundant in layer IV.

Conclusions. GLNase IR marks neurons that previous studies would predict as using an excitatory amino acid transmitter. Furthermore, the GLNase-Ir labeling of most infragranular pyramidal cells suggests that these neurons throughout the neocortex use a common transmitter. Although some layer III cells in the primate may also use this transmitter, our data suggest that there may be additional transmitters for pyramidal cells. The marked labeling of pyramidal cells with GLNase in contrast to AATase antibodies could further support the hypothesis that glutamate, or a glutamate-containing substance, is the transmitter for many cortical projection neurons. A more convincing method to dissociate these amino acids as separate transmitters remains to be developed. Our findings further suggest that the transmitter for layer $V$ and $V I$ pyramidal cells is consistent in mammals since these neurons are labeled in two different species of rodents and in a primate, although it would be desirable to examine a larger number of species. The variability in the pattern of labeling of layer III neurons suggests specializations of the organization of the superficial layers of different cortical fields within and between species.

\section{References}

Altschuler, R. A., G. R. Neises, G. G. Harmison, R. J. Wenthold, and J. Fex (1981) Immunocytochemical localization of aspartate aminotransferase immunoreactivity in cochlear nucleus of the guinea pig. Proc. Natl. Acad. Sci. U. S. A. 10: $6553-6557$.

Altschuler, R. A., J. L. Mosinger, G. G. Harmison, M. H. Parakkal, and R. J. Wenthold (1982) Aspartate aminotransferase-like immunoreactivity as a marker for aspartate/glutamate in guinea pig photoreceptors. Nature 298: 657-659.

Altschuler, R. A., R. J. Wenthold, A. M. Schwartz, W. G. Haser, N. P. Curthoys, M. H. Parakkal, and J. Fex (1984) Immunocytochemical localization of glutaminase-like immunoreactivity in the auditory nerve. Brain Res. 291: 173-178.

Altschuler, R. A., D. T. Monaghan, W. G. Haser, R. J. Wenthold, N. P. Curthoys, and C. W. Cotman (1985) Immunocytochemical localization of glutaminase-like and aspartate aminotransferase-like immunoreactivities in the rat and guinea pig hippocampus. Brain Res. 330: 225-233.

Baughman, R. W., and C. D. Gilbert (1981) Aspartate and glutamate as possible neurotransmitters in the visual cortex. J. Neurosci. 1: 427-439.

Bennet-Clarke, C., M. A. Romagnano, and S. A. Joseph (1980) Distribution of somatostatin in the rat brain: Telencephalon and diencephalon. Brain Res. 188: 473-486.

Berl, S., and H. Waelsch (1958) Determination of glutamic acid, glutamine 
glutathione and $\gamma$-aminobutyric acid and their distribution in brain tissue. J. Neurochem. 3: 161-169.

Bradford, H. F., and H. L. Ward (1976) On glutaminase activity in mammalian synaptosomes. Brain Res. 110: 115-125.

Bradford, H. F., H. L. Ward, and A. U. Thomas (1978) Glutamine as a substrate for nerve endings. J. Neurochem. 30: 1453-1459.

Bromberg, M. B., J. B. Penney, Jr., B. S. Stephenson, and A. B. Young (1981) Evidence for glutamate as the neurotransmitter of corticothalamic and corticorubral pathways. Brain Res. 215: 369-374.

Chronwall, B., and J. B. Wolf (1980) Prenatal and postnatal development of GABA accumulating cells in the occipital neocortex of the rat. J. Comp. Neurol. 190: 197-208

Cotman, C. W., and J. V. Nadler (1981) Glutamate and aspartate as hippocampal transmitters: Biochemical and pharmacological evidence. In Glutamate: Transmitter in the Central Nervous System, P. J. Roberts, J. Storm-Mathison, and G. A. R. Johnston, eds., pp. 117-151, John Witey \& Sons, Inc., London.

Curthoys, N. P., T. Kuhlenschmidt, and S. S. Godfrey (1976) Purification and characterization of phosphate dependent glutaminase from rat kidney. Arch. Biochem. Biophys. 174: 82-89.

Curtis, D. R., and G. A. R. Johnston (1974) Amino acid transmitters in the mammalian central nervous system. Ergebn. Physiol. 69: 97-188.

Divac, I., F. Fonnum, and J. Storm-Mathisen (1977) High affinity uptake of glutamate in tcrminals of corticostriatal axons. Naturc 266: 377-378.

Donoghue, J. P., and S. P. Wise (1982) The motor cortex of the rat: Cytoarchitecture and microstimulation mapping. J. Comp. Neurol. 212 $76-78$

Emson, P. C., and S. P. Hunt (1981) Anatomical chemistry of the cerebra cortex. In The Organization of the Cerebral Cortex, F. O. Schmitt, F. G. Worden, G. Adelman, and S. G. Dennsi, eds., pp. 325-346, MIT Press Cambridge, MA

Emson, P. C., and O. Lindvall (1979) Distribution of putative neurotransmitters in the neocortex. Neuroscience $4: 1-30$

Fex, J., R. A. Altschuler, R. J. Wenthold, and M. H. Parakkal (1982) Aspartate aminotransferase immunoreactivity in cochlea of guinea pig. Hear. Res. 7 149-160.

Fonnum, F. (1984) Glutamate: A neurotransmitter in mammalian brain. J. Neurochem. 42: 1-11.

Fonnum, F., J. Storm-Mathisen, and I. Divac (1981) Biochemical evidence for glutamate as neurotransmitter in corticostriatal and corticothalamic fibres in rat brain. Neuroscience 6: 863-874.

Foster, R. E., J. P. Donoghue, and E. F. Ebner (1981) Laminar organization of the efferent cells in the opossum somatic sensory-motor cortex. Exp. Brain Res. 43: 330-336.

Gilbert, C. D., and J. P. Kelly (1975) The projections of cells in different layers of the cat's visual cortex. J. Comp. Neurol. 163: 81-106.

Hamberger, A. C., C. W. Cotman, A. Sellstrom, and C. T. Weiler (1978) Glutamine, glial cells and their relationship to transmitter glutamate. In Dynamic Properties of Glial Cells, G. Franck, L. Hertz, and D. B. Tower, eds., p. 163, Plenum Press, New York.

Hassler, R., P. Haug, G. Nitsch, J. S. Kim, and K. Paik (1982) Effects of motor and premotor cortex ablations on concentration of amino acids, monoamines, and acetylcholine and on the ultrastructure in rat striatum. A confirmation of glutamate as the specific corticostriatal transmitter. J. Neurochem. 38: 1087-1098.

Hendrickson, A. E., S. P. Hunt, and J. -Y. Wu (1981) Immunocytochemical localization of glutamic acid decarboxylase in monkey striate cortex. Nature 292: $605-607$

Hendry, S. H., and E. G. Jones (1981) Sizes and distributions of intrinsic neurons incorporating tritiated GABA in monkey sensory-motor cortex. J. Neurosci. 1: 390-408.

Henke, H., and M. Cuenod (1980) Specific $\left({ }^{3} H\right)$ kainic acid binding in the vertebrate CNS. In Neurotransmitters and Their Receptors, U. Z. Littauer, Y. Dudai, I. Silman, V. I. Teichberg, and Z. Vogel, eds., pp. 373-390, John Wiley \& Sons, Inc., New York.

Hertz, L. (1979) Functional interactions between neurons and astrocytes. I Turnover and metabolism of putative amino acid transmitters. Prog. Neu robiol. 13: 277-323

Hicks, T. P., and R. C. A. Guedes (1983) Neuropharmacological properties of electrophysiologically identified, visually responsive neurones of the posterior lateral suprasylvian area. Exp. Brain Res. 49: 157-173

Innis, R. B., F. M. Correa, G. R. Uhi, B. Schneider, and S. Synder (1979) Cholecystokinin octapeptide-like immunoreactivity: Histochemical localization in rat brain. Proc. Natl. Acad. Sci. U. S. A 76:521-525.

Jones, E. G., and S. P. Wise (1977) Size, laminar and columnar distribution of efferent cells in the sensory-motor cortex of monkeys. $J$ Comp. Neurol. 175: $391-438$

Jones, E. G., J. D. Coulter, and S. H. C. Hendry (1978) Intracortical connectivity of architectonic fields in the somatic sensory, motor and parietal cortex of monkeys. J. Comp. Neurol. 181: 291-348.

Kerkerian, L., A. Nieoullon, and N. Dusticier (1983) Topographic changes in high-affinity glutamate uptake in the cat red nucleus, substantia nigra thalamus and caudate nucleus after lesions of sensorimotor cortical areas. Exp. Neurol. 81: 598-612.

Kim, J. -S., R. I lassler, P. I laug, and K. -S. Paik (1977) Effect of frontal cortex ablation on striatal glutamic acid level in rat. Brain Res. 132: 370-374

Krnjevic, K., and J. W. Phillis (1963) lontophoretic studies of neurons in the mammalian cerebral cortex. J. Physiol. (Lond.) 765: 274-304

Lin, C. -T., H. Z. Li, and V. -T. Wu (1983) Immunocytochemical localization of L-glutamate decarboxylase, gamma aminobutyric acid transaminase cysteinesulfinic acid decarboxylase, aspartate aminotransferase and somatostatin in rat retina. Brain Res. 270: 273-284

Logan, W. J., and S. H. Snyder (1971) Unique high affinity uptake systems for glycine, glutamic and aspartic acids in central nervous tissue of the rat. Nature 234: 297-299.

Lund, J. S., R. D. Lund, H. E. Hendrickson, A. H. Bunt, and A. F. Fuchs (1975) The origin of efferent pathways from the primary visual cortex area 17 of the cat. J. Comp. Neurol. 164: 287-303.

Lund-Karlsen, R., and F. Fonnum (1978) Evidence for glutamate as a neurotransmitter in the corticofugal fibers to the dorsal lateral geniculate body and the superior colliculus in rats. Brain Res. 151: 457-467

McDonald, J. K., J. G. Parnevelas, A. N. Karamanlidis, N. Brecha, and J. I. Koenig (1982) The morphology and distribution of peptide-containing neurons in the adult and developing visual cortex of the rat. I Somatostatin. J. Neurocytol. 11: 809-824.

McGeer, P. L., E. G. McGeer, V. Scherer, and K. Singh (1977) A glutamatergic cortico-striatal path? Brain Res. 128: 369-373.

McGinty, J. F., D. van der Kooy, and F. E. Bloom (1984) The distribution and morphology of opioid immunoreactive neurons in the cerebral cortex of rats. J. Neurosci $4 \cdot 1104-1117$

Morrison, J. H., B. R. Benoit, P. J. Magistretti, and F. E. Bloom (1983) Immunocytochemical distribution of pro-somatostatin related peptides in corcbral cortcx. Brain Rcs. 262: 344351.

Murray, E. A., and J. D. Coulter (1981) Organization of corticospinal neurons in the monkey. J. Comp. Neurol. 195: 339-365.

Nieoullon, A. and N. Dusticier (1983) Glulamale uptake, glularmate decarboxylase and choline acetyltransferase in subcortical areas after sensorimotor cortical ablations in the cat. Brain Res. Bull. 10:287-293.

Patel, A. J., A. Hunt, R. D. Gordon, and R. Balase (1982) The activities of different neuronal types of certain enzymes associated with the metabolic compartmentalization of glutamate. Dev. Brain Res. $4: 3$.

Peters, A., M. Miller, and L. M. Kimerer (1983) Cholecystokinin-like immunoreactive neurons in rat cerebral cortex. Neuroscience 8: 431-448.

Reubi, J. C., and M. Cuenod (1979) Glutamate release in vitro from corticostriatal terminals. Brain Res. 176: 185-188.

Reubi, J. C., C. Van der Berg, and M. Cuenod (1978) Glutamine as precursor for the GABA and glutamate transmitters pools. Neurosci. Lett. 10: 171 174

Ribak, C. (1978) Aspinous and sparsely-spinous stellate neurons contain glutamic acid decarboxylase in the visual cortex of rats. J. Neurocytol. 7. $461-478$.

Rustioni, A., and M. Cuenod (1982) Selective retrograde transport of Daspartate in spinal interneurons and cortical neurons of rats. Brain Res. 236: $143-155$.

Singer, H. S., J. T. Coyle, J. Frangia, and D. L. Price (1981) Effects of spina transection on presynaptic markers for glutamatergic neurons in the rat Neurochem. Res. 6: 485-496.

Soreide, A. J., and F. Fonnum (1980) High affinity uptake of D-Asp in the barrel subfield of mouse somatic sensory cortex. Brain Res. 201: $427-$ 430.

Spencer, H. (1976) Antagonism of cortical excitation of striatal neurons by glutamic acid diethyl ester: Evidence for glutamic acid as an excitatory transmitter in the rat striatum. Brain Res. 102: 91-101.

Stone, T. W. (1973) Cortical pyramidal tract interneurones and their sensitivity to L-glutamic acid. J. Physiol. (Lond.) 233: 211-225.

Stone, T. W. (1976) Blockade by amino acid antagonists of neuronal excitation mediated by the pyramidal tract. J. Physiol. (Lond.) 257: 187-198.

Stone, T. W. (1979) Amino acids as neurotransmitters of corticofugal neurones in the rat: A comparison of glutamate and aspartate. $\mathrm{Br}$. J. Pharmacol. 67: 545-551. 
Streit, P. (1980) Selective retrograde labeling indicating the transmitter of neuronal pathways. J. Comp. Neurol. 191: 429-464.

Thangnipon, W. T. Taxt, P. Brodal, and J. Storm-Mathisen (1980) Glutamate (Glu) and aspartate (Asp): Transmitters in the corticopontine pathway? Neurosci. Lett. Suppl. 5: 79.

Vogt, B. A., D. L. Rosene, and A. Peters (1981) Synaptic termination of thalamic and callosal afferents in cingulate cortex. J. Comp. Neurol. 201. 265-283.

Wenthold, R. J. (1981) Glutamate and aspartate as transmitters for auditory nerve. In Glutamate as a Neurotransmitter, G. DiChiara and G. L. Gessa, eds., pp. 69-78, Raven Press, New York.

Wenthold, R. J., and R. A. Altschuler (1983) Immunocytochemistry of aspar- tate aminotransferase and glutaminase. In Glutamine, Glutamate and GABA in the Central Nervous System, L. Hertz, E. Kvamme, E. G. McGeer, and A. Schoushoe, eds., pp. 33-50, Alan R. Liss, Inc., New York.

Welker, C. (1976) Receptive fields of barrels in the somatosensory neocortex of the rat. J. Comp. Neurol. 166: 173-190.

Wise, S. P., and E. G. Jones (1977) Cells of origin and terminal distribution of descending projections of the rat somatic sensory cortex. J. Comp. Neurol. 175: 129-158

Young, A. B., M. B. Bromberg, and J. B. Penney (1981) Decreased glutamate uptake in subcortical areas deafferented by sensorimotor cortical ablation in the cat. J. Neurosci. 1: 241-249. 